\title{
ANALISIS PARTISIPASI PEREMPUAN STUDI KASUS DI DEWAN PERWAKILAN RAKYAT DAERAH (DPRD) KABUPATEN KERINCI Oleh
}

\author{
Nanik Mandasari, S.IP, M,Si \\ Email : mandasarinanik@gmail.com
}

\begin{abstract}
Title. Analysis of Women's Participation Case Study in the Kerinci Regency Regional House of Representatives (DPRD). This research was carried out in the Kerinci Regency Regional House of Representatives (DPRD). Women's participation in the Kerinci Regency Regional Representative Council (DPRD) in the election of DPRD members has not participated maximally because only one female DPRD member is elected because women's participation is not as optimal as men's women's space and time limitations in entering politics there are still half measures and voters do not understand and know for sure the female candidates they have chosen. The research problem formulation is, What is the Participation of Women in the Kerinci Regency Regional Representative Council (DPRD)? The research objective is to find out the participation of women in the Kerinci Regency Regional Representative Council (DPRD). This research uses a qualitative approach where data is obtained through field interview guidelines for 5 informants referring to 6 research indicators namely 1. Formal education 2. Organizational Experience 3. Recruitment System 4. Social and Religious Perception 5. Cultural Perception 6. Cultural Perception. The data obtained in the field were analyzed based on the classification of the informant's answers described in the results and discussion of the study which was then interpreted by the researcher. it is known that Women's Participation in the Kerinci Regency Regional Representative Council (DPRD), for indicators one to six has not been carried out to the maximum that is women's participation in the Kerinci Regency Regional Representative Council (DPRD) has not been able to represent the number of women in the Kerinci Regency because women are elected in the Kerinci Regency Regional Representative Council (DPRD), only one person. For this reason, the writer suggests that the participation of women in the Kerinci Regency Regional Representative Council (DPRD) can be increased and the number is higher and women in the Kerinci Regency choose female candidates so that women's participation in the Kerinci Regency Regional Representative Council (DPRD) can contribute. in the development of the Kerinci Regency.
\end{abstract}

Keywords: Women's Participation 


\section{PENDAHULUAN}

Salah satu tahap penting yang mewarnai pelaksanaan otonomi daerah adalah ketika legislatif sebagai lembaga yang mewakili rakyat menjalankan fungsinya yaitu, fungsi legislasi, fungsi penganggaran, dan fungsi pengawasan. Fungsi legislasi dijalankan, antara lain dengan membuat Peraturan Daerah (perda). Fungsi ini menjadi sangat penting karena salah satu indikasi kesiapan daerah dalam merespon kebijakan otonomi daerah adalah ketika daerah mampu membuat kebijakan sendiri yang dituangkan dalam perda. Dalam hal ini, kemampuan legislasi menjadi sangat penting karena hal itu akan mempengaruhi kualitas dari produk kebijakan yang ditetapkan. Sementara itu wacana yang berkembang di masyarakat menunjukkan adanya keprihatinan terhadap kemampuan legislatif dalam melakukan legal drafting (rencana perda). Itulah sebabnya mengapa inisiatif pembuatan Rancangan Peraturan Daerah selalu berasal dari ekskutif

Tingkat representasi perempuan yang rendah di lembaga legislatif merupakan pelanggaran hak-hak demokratik fundamental perempuan, yang berarti hak-hak dasar mereka, diantaranya; hak untuk mengungkapkan pendapat, hak dalampencalonan menjadi anggota lembaga perwakilan, dan hak pencalonan menjadi presiden dan hal-hal lain yang mengandung persekutuan dan penyampaian pendapat yang berkaitan dengan politik.

Partisipasi politik perempuan adalah kegiatan sukarela kaum prempuan yang tergabung pada komunitas kaukus perempuan politik. Kasus ini terdiri dari berbagai unsur, antara lain pemerhati politik, aktivis perempuan, dosen, perempuan parlemen, kader perempuan partai politik dan lain sebagainya, sehingga dalam kaukus ini mereka mengambil bagian pada proses pemilihan penguasa, baik secara langsung atau tidak langsungdalam proses pembentukan kebijakan umum. Menurut Myron Wiener, sifat sukarela dari partisipasi adalah tidak ada pemaksaan, termasuk partisipasi perempuan politik yang dilakukan oleh para komunitas kaukus perempuan politik. Hal ini pada hakekatnya adalah usaha menggali dan memberdayakan potensi-potensi yang dimiliki oleh perempuan.

Dalam menjalankan partisipasinya perempuan mendapatkan banyak kendala. Menurut Lycette(1994:42) terdapat paling sedikit empat kendala bagi perempuan dalam berpartisipasi di bidang politik, yaitu disebabkan karena:

1. Perempuan menjalankan dua peran sekaligus, yaitu peran reproduktif dan peran produktif, di dalam maupun di luar rumah.

2. Perempuan relatif memiliki pendidikan yangrendah dibanding dengan laki-laki karena perbedaan kesempatan yang diperoleh.

3. Adanya hambatan budaya yang terkait dengan pembagian kerja secara seksual danpola interaksi perempuan dengan laki-laki yang membatasi gerak perempuan.

4. Adanya hambatan legal bagi perempuan, seperti larangan kepemilikan tanah, larangan berpartisipasi dalam pendidikan atau program Keluarga Berencana tanpa persetujuan dari suami atau ayahnya.

Di antara bentuk partisipasi nyata perempuan adalah dengan melihat keterwakilan mereka dipanggung politik dan lembaga politik formal. Secara realitas, ternyata di Indonesia jumlah perwakilan perempuan masih sangat rendah dibandingkan laki-laki. Dalam lembaga legislative, keterwakilan perempuan amat kecil, tidak seimbang dengan jumlah mereka.

Kuatnya pengaruh budaya bangsa ini pada politik lambat laun membentuk budaya politik yang kemudian menjadi cara pandang dan persepsi masyarakat mengenai politik. Politik selalu dihubungkan dengan hal-hal yang bersifat maskulin yang dianggap kontras dengan sifat-sifat keperempuanan yang feminin. Perempuan dianggap tidak cocok untuk terjun di dunia politik yang keras karena menganggap bahwa perempuan memiliki watak yang lemah lembut, tidak kuat, 
dantidak tegas. Perempuan juga dianggap tidak akan mampu menjadi pimpinan sebuah organisasi, partai politik atau pemerintahan. Banyak perempuan yang memiliki pendidikan dan kemampuan yang tinggi, tetapi karena terikat dengan budaya patriarki ini, mereka tidak berminat terjun dalam dunia politik termasuk menjadi calon anggota legislatif.

Budaya politik ini juga sangat kuat pengaruhnya kepada orientasi politik masyarakat terutama partai politik dalam perekrutan kader dan penjaringan calon legislatif. Orientasi politik memegang peran penting dalam penjaringan calon legislatif, baik di tingkat pusat maupun di daerah. Dengan adanya persepsi negatif tentang perempuan dalam dunia politik mengakibatkan orientasi politik perempuan juga negatif dan akibatnya perempuan marjinal dalam komposisi calon legislatif. Sebaliknya, calon legislatif laki-laki karena dipersepsi positif menyebabkan jumlah mereka dominan di dalamnya.

Partisipasi perempuan di wilayah politik perlu diupayakan dengan memaksimalkan dan memberdayakan perempuan itu sendiri, selainjuga strategi komunikasi politik yang jitu, sehingga perempuan bisa maksimal berpartisipasi, termasuk mendapatkan perwakilan di legislatif yang sesuai dengan jumlah mereka di masyarakat. Keterbatasan partisipasi perempuan akan sangat memengaruhi, baik secara langsung maupun tidak langsung, terhadap upaya pengembangan masyarakat, termasuk juga pemberdayaan perempuan. Jika tingkat partisipasi politik masyarakat termasuk di dalamnya perempuan rendah, maka ada indikasi bahwa pelaksanaan demokrasi yang dilaksanakan di suatunegara memberi tanda yang kurang baik, dan hal tersebut tentu saja akan sangat merugikan bagi bangsa dan negara.

Namun apabila melihat kenyataan yang ada dilapangan dari jumlah keterwakilan perempuan di DPRD Kabupaten/Kabupaten yang masih di bawah 30\% maka dari segi kuantitas kepentingan perempuan belum terwakili sepenuhnya. Karena secara logika semakin banyak jumlah perempuan di DPRD maka akan semakin banyak kepentingan perempuan dapat terakomodasi.Apalagi jika masalah partisipasi perempuan di DPRD ini dikaitkan dengan mekanisme pembentukan peraturan daerah yang ada di DPRD. Maka dari hasil penelitian dapat disimpulkan bahwa mekanisme pembentukan peraturan daerah di DPRD Kabupaten tidak berbeda karena semuanya melalui mekanisme yang sama dalam hal pembahasan rancangan peraturan daerah di DPRD.

Melihat mekanisme pembentukan peraturan daerah di DPRD maka sebenarnya diharapkan perlunya partisipasi perempuan di setiap tahapan pembentukan peraturan daerah tersebut. Dengan sedikitnya perempuan yang duduk di DPRD maka dapat dikatakan bahwa dalam tahapan pembentukan peraturan daerah tersebut tidak semua anggota DPRD perempuan dapat terlibat di dalamnya ini sebagai konsekuensi dari rendah partisipasi perempuan di DPRD Kabupaten.

Demikian pula halnya ketika sebuah rancangan peraturan daerah itu di bahas di masingmasing fraksi. Karena tidak setiap fraksi memiliki anggota DPRD perempuan maka pada saat pembahasan di tingkat fraksi pun akan mengalami hambatan karena kurangnya suara perempuan yang ada di fraksi. Tanpa ada partisipasi perempuan pada semua tahapan pembahasan rancangan peraturan daerah tersebut maka isu kesetaraan pada pelaksanaan pembangunan tidak dapat sepenuhnya dapat tercapai karena isu kesetaraan dan keadilan itu haruslah di lihat pada perspektif yang seimbang antara laki-laki dan perempuan.

Selain itu partisipasi perempuan dalam pengambilan kebijakan di legislatif di pandang sebagai suatu kondisi yang diperlukan agar kepentingan perempuan dipertimbangkan. Rendahnya partisipasi perempuan dalam pembuatan kebijakan di tingkat daerah dan ketiadaan perspektif gender dalam pembuatan kebijakan termasuk pembentukan peraturan daerah maka dapat 
menimbulkan konsekuensi yang dapat merugikan rakyat khususnya perempuan. Artinya kebijakan desentralisasi yang dijalankan tanpa melibatkan perempuan belum sepenuhnya mampu mengakomodir kepentingan perempuan terutama kepentingan perempuan yang ada di daerah tersebut.

Keterwakilan ini baru pada tataran kuantitas, belum menyangkut aspek kualitas, artinya secara kuantitas saja perempuan tidak terwakili bagaimana dengan kualitas yang dimiliki oleh perempuan tersebut. Padahal hampir setengah jumlah massa pemilih pada setiap pemilu adalah perempuan dan sangat ironis pula jumlah yang besar ini tidak sampai mencapai angka $30 \%$.

\section{Jumlah Anggota Perempuan DPRD Kabupaten Kerinci}

Pemilu 2019 menghasilkan jumlah anggota DPRD Kabupaten Kerinci sebagaimana tergambar pada Tabel 1. Secara umum, Tabel 1 memperlihatkan bahwa jumlah perempuan di DPRD Kabupaten Kerinci masih jauh sekali jumlahnya.

Tabel 1.1

\section{Komposisi Anggota DPRD Kabupaten Kerinci Masa Jabatan 2019-2024 Berdasarkan Partai Politik dan Jenis Kelamin}

\begin{tabular}{|c|l|c|c|c|}
\hline No & \multicolumn{1}{|c|}{ Partai } & Laki-laki & Perempuan & Total \\
\hline 1 & GERINDRA & 5 & - & 5 \\
2 & PAN & 5 & - & 5 \\
3 & GOLKAR & 4 & - & 4 \\
4 & PKB & 4 & - & 4 \\
5 & PDIP & 3 & - & 3 \\
6 & PKS & 3 & - & 3 \\
7 & DEMOKRAT & 2 & 1 & 3 \\
8 & NASDEM & 2 & - & 1 \\
9 & PERINDO & 1 & - & $\mathbf{3 0}$ \\
\hline
\end{tabular}

Sumber: DPRD Kabupaten Kerinci 2019

Dari data tabel 1.1 diatas dapat dilihat bahwa dari sembilan partai yang ikut dalam pemilihan umum tahun 2019 untuk periode 2019-2024 yang terpilih dari anggota partai yang perempuan hanya 1 orang. Dengan demikian dapat disimpulkan bahwa partisipasi perempuan di DPRD Kabupaten Kerinci sangat kurang.

Data ini tentunya dapat menepis anggapan bahwa pada umumnya perempuan akan ditempatkan pada bidang-bidang yang dekat dengan peran tradisional seperti bidang kesehatan, pendidikan, dan peran perempuan (bidang kesejahteraan rakyat). Dengan kata lain komisi ini adalah komisi yang memiliki anggota perempuan terbesar. Dan pada periode ini tidak ada satupun perempuan yang menduduki posisi sebagai pimpinan pada komisi maupun alat kelengkapan 
DPRD lainnya. Mungkin masih terdapat hambatan bagi mereka untuk mempengaruhi keputusan DPRD karena jumlah mereka yang lebih sedikit.

Mengambil satu keputusan dilakukan pemungutan suara (voting), maka jumlah perempuan di dalam masing-masing komisi tidak akan memungkinkan mereka untuk meraih kemenangan. Belum lagi jika diingat bahwa keberadaan para anggota DPRD tentunya tidak bisa dilepaskan dari peran partai (fraksi) nya. Bagaimanapun harus diingat bahwa didalam diri seorang anggota DPRD terdapat bermacam dimensi perwakilan, baik itu sebagai perwakilan rakyat, perwakilan partai, maupun perwakilan diri pribadinya. Bisa saja dimensi-dimensi ini tidak dapat diselaraskan pada saat yang bersamaan. Tidak jarang kepentingan pribadi dan partai mengalahkan kepentingan rakyat.

Ketika perempuan kurang dapat memaksimalkan keterlibatannya secara aktif dalam pembentukan peraturan daerah maka perempuan dapat dikatakan telah menghilangkan kesempatan yang dimilikinya untuk memperjuangkan aspirasi dan kepentingan perempuan serta mempengaruhi kebijakan yang di buat tersebut. Inilah kenapa pentingnya keterlibatan perempuan secara aktif dalam setiap tahapan pembentukan peraturan daerah. Agaknya perlu dipikirkan secara lebih mendalam lagi bahwa sesungguhnya yang dibutuhkan bagi kemajuan bangsa Indonesia di masa depan bukan sekedar memenuhi kuota 30\% tersebut melainkan bagaimana mempersiapkan perempuan dengan memberikan fasilitas dan kesempatan yang memadai sehingga dapat turut serta aktif ke dunia politik, untuk itu diharapkan kuantitas perempuan akan meningkat di legislatif dengan diiringi kualitas sumber daya perempuan. Sehingga di masa depan tidak lagi ditemukan wakil-wakil perempuan di legislatif yang hanya menjadi pelengkap semata. Sebab yang diperlukan oleh bangsa ini bukan hanya perempuan dalam arti fisik semata, melainkan perempuan yang memiliki komitmen dan kemauan pada upaya pemberdayaan perempuan, perempuan yang dapat menyuarakan kepentingan dan memperjuangkan kepentingan perempuan secara khusus dan kepentingan masyarakat secara umum. Dari latar belakang permasalahan diatas maka penulis tertarik meneliti dengan judul " Analisis Partisipasi Perempuan (Studi Kasus di Dewan Perwakilan Rakyat Daerah (DPRD) Kabupaten Kerinci)".

\section{Perumusan Masalah.}

Berdasarkan kenyataan diatas, maka masalah yang akan dikaji dalam penelitian ini dapat dirumuskan Bagaimanakah Partipasi Perempuan di Dewan Perwakilan Rakyat Daerah (DPRD) Kabupaten Kerinci?

\section{Tinjauan Pustaka \\ Partisipasi}

Partisipasi selain telah menjadi kata kunci dalam pembangunan juga menjadi salah satu karakteristik dari penyelanggaraan pemerintah yang baik. Secara etimologi, partisipasi berasal dari bahasa Inggris "participation" yang berarti mengambil bagian/keikutsertaan. Dalam kamus lengkap bahasa Indonesia dijelaskan "partisipasi" berarti: hal turut berperan serta dalam suatu kegiatan, keikutsertaan, peran serta. Secara umum pengertian dari partisipasi dalam pembangunan adalah keperansertaan semua anggota atau wakil-wakil masyarakat atau rakyat untuk ikut membuat keputusan dalam proses perencanaan dan pengelolaan pembangunan termasuk di dalamnya memutuskan rencana-rencana kegiatan yang akan dilaksanakan, manfaat yang akan diperoleh, serta bagaimana melaksanakan dan mengevaluasi hasil pelaksanaannya. 
Banyak ahli memberikan pengertian mengenai konsep partisipasi. Bila dilihat dari asal katanya, kata partisipasi berasal dari kata bahasa Inggris "participation"yang berarti pengambilan bagian, pengikutsertaan(John M. Echols \& Hasan Shadily, 2000:419). Partisipasi berarti peran serta seseorang atau kelompok masyarakat dalam proses pembangunan baik dalam bentuk pernyataan maupun dalam bentuk kegiatan dengan memberi masukan pikiran, tenaga, waktu, keahlian, modal dan atau materi, serta ikut memanfaatkan dan menikmati hasil -hasil pembangunan (I Nyoman Sumaryadi, 2010:46). Pengertian tentang partisipasi dikemukakan oleh Fasli Djalal dan Dedi Supriadi, (2001:201) dimana partisipasi dapat juga berarti bahwa pembuat keputusan menyarankan kelompok atau masyarakat ikut terlibat dalam bentuk penyampaian saran dan pendapat, barang, keterampilan, bahan dan jasa. Partisipasi dapat juga berarti bahwa kelompok mengenal masalah mereka sendiri, mengkaji pilihan mereka, membuat keputusan, dan memecahkan masalahnya.

H.A.R.Tilaar, (2009:287) mengungkapkan partisipasi adalah sebagai wujud dari keinginan untuk mengembangkan demokrasi melalui proses desentralisasi dimana diupayakan antara lain perlunya perencanaan dari bawah (bottom-up) dengan mengikutsertakan masyarakat dalam proses perencanaan dan pembangunan masyarakatnya. Menurut Sundariningrum dalam Sugiyah (2001: 38) mengklasifikasikan partisipasi menjadi 2 (dua) berdasarkan cara keterlibatannya, yaitu: a). Partisipasi Langsung. Partisipasi yang terjadi apabila individu menampilkan kegiatan tertentu dalam proses partisipasi. Partisipasi ini terjadi apabila setiap orang dapat mengajukan pandangan, membahas pokok permasalahan, mengajukan keberatan terhadap keinginan orang lain atau terhadap ucapannya. b). Partisipasi tidak langsung. Partisipasi yang terjadi apabila individu mendelegasikan hak partisipasinya.

Cohen dan Uphoff (2011:63) membedakan partisipasi menjadi empat jenis, yaitu pertama, partisipasi dalam pengambilan keputusan. Kedua, partisipasi dalam pelaksanaan. Ketiga, partisipasi dalam pengambilan pemanfaatan. Dan Keempat, partisipasi dalam evaluasi. Indikator partisipasi yaitu:

1. Partisipasi dalam pengambilan keputusan.

2. Partisipasi dalam pelaksanaan

3. Partisipasi dalam pengambilan manfaat.

4. Partisipasi dalam evaluasi.

Berdasarkan beberapa definisi diatas maka dapat disimpulkan bahwa partisipasi adalah keterlibatan suatu individu atau kelompok dalam pencapaian tujuan dan adanya pembagian kewenangan atau tanggung jawab bersama.

\section{Perempuan dan Rekrutmen Politik}

Menurut Miftah Thoha (2003:24) bahwa ada tiga sistem yang sering digunakan dalam proses rekrutmen yaitu:

1. Sistem patronit (patronage system).

2. Sistemmerita (merit system).

3. SistemKarir (career system).

Berdasarkan ketiga sistem tersebut, maka dalam proses rekrutmen diharapkan memperhatikan sistem yang dipergunakan, agar pengaruh yang positif dengan mengarah kepada objektivitas anggota sesuai dengan kemampuan dan keahlian, tingkat pendidikan, pengalaman berorganisasi (kinerja) dan profesionalisme.

Pola rekrutmen yang dipraktekkan oleh suatu sistem politik dapat dipandang sebagai cerminan dari masyarakat dimana sistem politik itu berlaku dan sekaligus juga dapat mempengaruhi masyarakat itu sendiri. Sebagai faktor yang mempengaruhi masyarakat, pola 
rekrutmen adalah merupakan jalan bagi masyarakat untuk dapat hidup berperan serta dalam sistem politik, mempengaruhi kebijakan yang akan diambil, mempercepat stabilitas sistem. Sedangkan sebagai faktor yang dipengaruhi pola rekrutmen dapat menjadi cerminan nilai masyarakat, tingkat konsistensi dan kontradiksinya, derajat dan tipe perwakilan, basis stratifikasi sosial dan bentuk artikulasinya dengan sistem politik. Dengan demikian melalui pola rekruitmen elit yang dilakukan oleh suatu sistem politik, kita dapat melihat tingkat perkembangan masyarakat.

Berbicara tentang perempuan dalam pemilihan legislatif, merupakan bahasan yang menarik. Sebab, partisipasi perempuan dari perspektif kalangan feminisme radikal adalah dimana terjadinya transformal total, peran perempuan di ranah domestik ke ranah publik. Atau dalam bahasa populernya, kesetaraan gender (Huntington \& Nelson, 1994). Keterlibatan wanita di kancah politik bukan hal yang baru. Dalam sejarah perjuangan kaum wanita, partisipasi wanita dalam pembangunan, telah banyak kemajuan yang telah dicapai terutama di bidang pendidikan, ekonomi, sosial, budaya dan bidang pemerintahan. Penelitian Terdahulu

Penelitian ini dilkaukan oleh Oktaviani Adhi Suciptaningsih tahun 2010 dengan judul "Partisipasi Perempuan dalam Legislatif di kabupaten Kendal". Partisipasi perempuan dalam politik merupakan bentuk emansipasi yang penting bagi perempuan untuk mencapai kesetaraan gender. Dalam penelitian ini, saya mengeksplorasi bagaimana partisipasi perempuan dalam Lembaga Legislatif di Kabupaten Kendal dan bagaimana peran perempuan dalam penentuan kebijakan di Lembaga Legislatif di Kabupaten Kendal. Metode penelitian menggunakan pendekatan kualitatif, pengumpulan data dilakukan dengan observasi, wawancara dan dokumentasi. Hasil penelitian menunjukkan bahwa partisipasi perempuan dalam Lembaga Legislatif di Kabupaten Kendal masih sangat rendah, dari 45 orang anggota dewan legislatif, hanya 4 orang saja yang perempuan. Padahal jumlah penduduk perempuan lebih banyak daripada penduduk laki-laki. Rendahnya partisipasi perempuan ini disebabkan karena banyaknya kendala yang menghambat perempuan untuk maju berpartisipasi dalam lembaga legislatif, diantaranya kendala psikologis, ekonomi, politik, dan sosial budaya. Yang sedikit inipun tidak memiliki kompetensi yang baik untuk memperjuangkan keadilan jender dalam kebijakan. Akibatnya, banyak kebijakan publik yang belum berperspektif gender.

\section{Kerangka Pemikiran}

Indikator penelitian diambil dari pendapat Mulyana W. Kusuma (2006:22)

1. Pendidikan Formal

2. Pengalaman Organisasi

3. Sistem Rekruitmen

4. Persepsi Sosial dan Agama

5. Persepsi Budaya (Kultural)

6. Persepsi Masyarakat

Gambar 1.1

Indikator Penelitian

\section{Partisipasi}

1. Pendidikan formal

2. Pengalaman Organisasi

3. Sistem Rekruitment

4. Persepsi Sosial dan Agama 
Sumber : Mulyana W. Kusuma (2006:22)

\section{Metode Penelitian \\ Pendekatan Penelitian}

Dalam Penelitian ini penulis menggunakan pendekatan Kualitatif yaitu meneliti suatu objek penelitian dengan mengkaji secara keseluruhan dan mendalam bukan melihat hubungan dua variabel atau lebih. Dimana hasil penelitian akan diolah berdasarkan interpretatif peneliti dan diuraikan dalam bentuk deskriptif. Lexy J.Moleong (2009: 21)

\section{Metode Pengumpulan Data}

1. Penelitian Perpustakaan (Library Research)

2. Penelitian Lapangan (Field Research)
a. Wawancara (interview)
b. Observasi (observation)

\section{Jenis Data}

Untuk keperluan penelitian ini, adapun jenis data yang penulis gunakan adalah:

1. Data Primer

2. Data Sekunder

\section{Metode Penarikan Informan}

Metode penarikan informan adalah merupakan teknik pengambilan sampel untuk menentukan sampel yang akan digunakan dalam penelitian. Sugiono, (2007:91). Dalam penelitian Kualitatif proses sampling yang terpenting adalah bagaimana menentukan informan kunci atau situasi sosial tertentu yang sarat informasi sesuai dengan fokus penelitian. Bugin, (2003:53). Pemilihan informan kunci diperolah secara purposife sampling yaitu sampel yang diambil secara sengaja dan informan biasa dilakukan dengan cara accidental sampling yaitu sampel yang ditemukan secara kebetulan oleh peneliti yaitu masyarakat perempuan yang ikut dalam pemilihan anggota legislatif pada tahun 2019 di Kabupaten Kerinci.

Mengacu pada pendapat ahli diatas dalam penelitian ini penulis mengambil informan dengan kriteria, yaitu : masyarakat dari perempuan-perempuan di Kabupaten Kerinci, yang ikut dalam pemilihan anggota legislatif tahun 2019 dengan alasan karena dalam penelitian ini membahas tentang partisipasi perempuan dalam pemilihan anggota legislatif di Kabupaten Kerinci yaitu yang ikut memilih. Jumlah informan yang diwawancarai 5 orang yang diperoleh secara acsidental sampling yaitu sampel yang terpilih secara kebetulan yang memenuhi persayaratan untuk menjadi informan, yang dapat dilihat pada tabel 1.1 di bawah ini.

\section{Tabel 1.1.}




\section{Infroman Penelitian}

\begin{tabular}{|c|l|}
\hline NO & \multicolumn{1}{|c|}{ NAMA } \\
\hline 1 & EDMINUDDIN, SE. MM \\
2 & YULDI HERMAN, SE. MM \\
3 & LISNURBANI, S.Pd \\
4 & RENO EFENDI, ST \\
5 & AMRIZAL \\
\hline
\end{tabular}

Sumber : DPRD Kabupaten Kerinci Tahun 2019

\section{Metode Analisis Data}

Mengacu pada tujuan penulisan ini yakni untuk mengatahui partisipasi perempuan di Dewan Perwakilan Rakyat Daerah (DPRD) Kabupaten Keirnci. Peneliti menggunakan informan kunci dan biasa berdasarkan tingkat kejenuhan yang akan diperoleh dalam penelitian nantinya yang akan diwawancarai dengan menggunakan pedoman wawancara untuk memperoleh data dilapangan.

Metode analisis yang digunakan dalam penelitian ini yaitu data yang diperoleh dilapangan dan diolah dengan menggunakan interpretatif peneliti untuk mengolah data mentah yang relevan yang diperoleh dilapangan kemudian hasil penelitian diuraikan dalam bentuk kalimat bukan angka-angka atau data statistik.

Menurut Miles dalam Emzir (2010 : 129)

Analisa data ada tiga cara yaitu :

a. Reduksi data

b. Model data (data display)

c. Penarikan/Verifikasi kesimpulan

Untuk menjaga validitas data maka dilakukan triangulasi baik terhadap data, sumber maupun metode.

a. Triangulasi sumber

b. Triangulasi data,

c. Triangulasi metode

\section{Lokasi Penelitian}

Penelitian ini akan dilakukan di Kabupaten Kerinci, dengan alasan berdasarkan pengamatan awal peneliti diindikasikan bahwa partispasi perempuan di Dewan Perwakilan Rakyat Daerah (DPRD) Kabupaten Kerinci sangat kurang.

\section{HASIL PENELITIAN DAN PEMBAHASAN \\ 1. Partisipasi Perempuan Studi Kasus di Dewan Perwakilan Rakyat Daerah (DPRD) Kabupaten Kerinci}


Dalam penelitian ini dilakukan di Dewan Perwakilan Rakyat Daerah (DPRD) Kabupaten Kerinci dengan melihat permasalahan penelitian dimana partisipasi perempuan di Dewan Perwakilan Rakyat Daerah (DPRD) Kabupaten Kerinci sangat kurang. Informan dalam penelitian diperoleh 5 orang yang kemudian diwawancarai dengan menggunakan pedoman wawancara.

\section{Pendidikan Formal.}

Ketika wawancara dengan informan tentang, bagaimanakah partisipasi perempuan secara pendidikan formal di Dewan Perwakilan Rakyat Daerah (DPRD) Kabupaten Kerinci ? Jawaban dari informan yaitu:

"perempuan belum dapat sepenuhnya berpartisipasi di Dewan Perwakilan Rakyat Daerah (DPRD) walapun secara pendidikan Formal sudah cukup tinggi dikarenakan jumlahnya dalam keanggotaan Dewan Perwakilan Rakyat Daerah (DPRD) Kabupaten Kerinci yang tidak banyak sehingga tidak dapat mewakili suara perempuan sepenuhnya."

(Hasil wawancara dengan Amrizal pukul 10.30 Wib hari Kamis tanggal 09 Januari 2020)

"partisipasi perempuan dalam Dewan Perwakilan Rakyat Daerah (DPRD) secara pendidikan formal untuk menjadi anggota legislatif pada pemilihan legislatif hanya untuk melengkapi jumlah anggota perempuan $30 \%$ pada setiap partai dalam artian hanya memenuhi persyaratan jumlah anggota perempuan, belum sepenuhnya dapat berpartisipasi sebagaimana partisipasi anggota legislatif laki-laki ."

(Hasil wawancara dengan Reno Efendi pukul 12.00 Wib hari Kamis tanggal 09 Januari 2020)

"keberadaan perempuan di Dewan Perwakilan Rakyat Daerah (DPRD) secara pendidkan formal belum dapat sepenuhnya berpartisipasi karena keterbatasan jumlah Anggota perempuan yang terpilih."

(Hasil wawancara dengan Lisnurbani pukul 11.30 Wib hari Kamis tanggal 09 Januari 2020)

"partisipasi perempuan secara pendidikan formal di Dewan Perwakilan Rakyat Daerah (DPRD) tidak dapat mewakili jumlah perempuam yang hanya terpilih satu orang."

(Hasil wawancara dengan Yuldi Herman pukul 10.00 Wib hari Kamis tanggal 09 Januari 2020)

"pada prinsipnya perempuan belum dapat sepenuhnya berpartisipasi dalam Dewan Perwakilan Rakyat Daerah (DPRD) perempuan memiliki keterbatasan dalam memasuki kancah politik karena adanya keterbatasan ruang dan gerak perempuan yang jumlahnya tidak dapat mewakili jumlah perempuan di Kabupaten Kerinci."

(Hasil wawancara dengan Edminuddin pukul 14.30 Wib hari Kamis tanggal 09 Januari 2020)

Berdasarkan dari jawaban informan dapat diinterpretasikan, bahwa partisipasi perempuan di Dewan Perwakilan Rakyat Daerah (DPRD) tidak sepenuh dapat dilakukan oleh perempuan karena adanya keterbatasan ruang dan gerak perempuan dalam kancah politik dikarenakan jumlah perempuan yang terpilih tidak mewakili jumlah perempuan di Kabupaten Kerinci.

\section{Pengalaman Organisasi.}


Ketika wawancara dengan informan tentang, bagaimanakah pengalaman organisasi perempuan di Dewan Perwakilan Rakyat Daerah (DPRD) Kabupaten Kerinci ? Jawaban dari informan yaitu:

"Pengalaman Organisasi perempuan di Dewan Perwakilan Rakyat Daerah (DPRD) Kabupaten Kerinci belum sepenuhnya memiliki pengalaman beroganisasi hal inilah yang membuat perempuan tidak begitu populer dimata masyarakat sehingga jumlah perempuan yang terpilih di Dewan Perwakilan Rakyat Daerah (DPRD) tidak banyak."

(Hasil wawancara dengan Amrizal pukul 10.30 Wib hari Kamis tanggal 09 Januari 2020)

"partisipasi perempuan dalam berorganisasi pelaksanaan belum sepenuhnya dilakukan dengan maksimal. Hal ini dapat dilihat dari keseriusan perempuan dalam partai politik yang hampir ada pada setiap partai politik kehadiran perempuan hanya sekedar pelengkap kuota keanggotaan perempuan dalam partai dalam pelaksanaannya perempuan tidak semaksimal laki-laki terutama dalam pengalaman berorganisasi di masyarakat."

(Hasil wawancara dengan Reno Efendi pukul 12.00 Wib hari Kamis tanggal 09 Januari 2020)

"kehadiran perempuan di Dewan Perwakilan Rakyat Daerah (DPRD) belum dapat memenuhi suara perempuan. Apalagi dalam pelaksanaan kegiatan-kegiatan partai. Bahkan perempuan yang ikut dalam pemilihan anggota Dewan Perwakilan Rakyat Daerah (DPRD) Kabupaten hanya sekedar untuk dapat memenuhi kuota sebagai prasyarat suatu partai untuk dapat masuk menjadi peserta tidak diiringi dengan pengalaman berorganisasi di masyarakat."

(Hasil wawancara dengan Lisnurbani pukul 11.30 Wib hari Kamis tanggal 09 Januari 2020)

"dalam pelaksanaannya partisipasi perempuan dalam berorganisasi tidak dapat membuat perempuan banyak terpilih di Dewan Perwakilan Rakyat Daerah (DPRD) di karenakan pengalaman berorganisasi yang sangat kurang pada perempuan baik yang terpilih maupun yang tidak terpilih. Karena tidak banyak yang dapat dilakukan oleh perempuan untuk dapat menjadi anggota terpilih dikarena pelaksanaannya tidak dilakukan secara serius seperti halnya anggota Dewan Perwakilan Rakyat Daerah (DPRD) yang laki-laki."

(Hasil wawancara dengan Yuldi Herman pukul 10.00 Wib hari Kamis tanggal 09 Januari 2020)

"Partisipasi perempuan belum dapat dikatakan maksimal. Keseriusan anggota legislatif perempuan masih setengah-setengah untuk terjun sebagai anggota legislatif dikarenakan kehadiran perempuan tidak diiringi dengan pengalaman berorganisasi karena untuk terjun secara serius agar dapat terpilih tentunya harus populer di mata masyarakat yang tentunya harus didukung pengalaman berorganisasi sedangkan partisipasi perempuan di Dewan Perwakilan Rakyat Daerah (DPRD) pengalamannya minim dalam bidang berorganisasi." (Hasil wawancara dengan Edminuddin pukul 14.30 Wib hari Kamis tanggal 09 Januari 2020)

Berdasarkan dari jawaban informan dapat diinterpretasikan, bahwa partisipasi perempuan di Dewan Perwakilan Rakyat Daerah (DPRD) belum dapat perpartisipasi secara maksimal 
dikarenakan partisipasi perempuan untuk terjun secara serius tidak diiringi dengan keseriusan dan minimnya pengalaman dalam berorganisasi.

\section{Sistem Rekruitmen.}

Ketika wawancara dengan informan tentang, bagaimanakah sistem rekruitmen perempuan di Dewan Perwakilan Rakyat Daerah (DPRD) Kabupaten Kerinci ? Jawaban dari informan yaitu: "Sistem rekruitmen perempuan di Dewan Perwakilan Rakyat Daerah (DPRD) sudah dilakukan sesuai peraturan yang ada. Dimana dengan adanya peraturan $30 \%$ pada setiap anggota partai politik dan hal ini sangat dimanfaatkan oleh perempuan di Kabupaten Kerinci hanya saja belum dapat berperan aktif secara maksimal dikarenakan tidak diiringi dengan kualitas perempuannya."

(Hasil wawancara dengan Amrizal pukul 10.30 Wib hari Kamis tanggal 09 Januari 2020)

"adanya peraturan anggota partai politik harus ada memenuhi kuota anggota perempuan sebanyak 30\%, dalam hal ini perempuan dengan tangan terbuka mengambil kesempatan tersebut bagi perempuan yang ingin ikut andil dalam kancah politik. Walaupun tidak banyak perempuan yang ingin berperan aktif tapi adanya kesempatan tersebut menjadi peluang bagi perempuan untuk dapat berkarya dalam partai, hanya saja dalam perekrutannya tidak diiringi dengan kualitas dan kapabilitas perempuannya."

(Hasil wawancara dengan Reno Efendi pukul 12.00 Wib hari Kamis tanggal 09 Januari 2020)

"kehadiran perempuan dalam partai politik belum dapat dikatakan maksimal. Tetapi adanya jumlah yang cukup besar dalam sistem rekruitmen memberikan peluang bagi perempuan untuk dapat berperan aktif dalam partai politik, dan tentu saja perempuan juga termotivasi untuk ikut andil memanfaatkan peluang tersebut tetapi tidak sepenuhnya loyalitas terhadap partainya."

(Hasil wawancara dengan Lisnurbani pukul 11.30 Wib hari Kamis tanggal 09 Januari 2020)

"partisipasi perempuan di Dewan Perwakilan Rakyat Daerah (DPRD) Kabupaten Kerinci belum sepenuhnya dapat meningkatkan jumlah anggota terpilih di Dewan Perwakilan Rakyat Daerah (DPRD) Kabupaten Kerinci dikarenakan kurangnya kualitas dan kapabilitas dari anggota perempuan itu sendiri, sehingga kehadiran perempuan di Dewan Perwakilan Rakyat Daerah (DPRD) Kabupaten Kerinci tidak dapat memenuhi suara perempuan yang jumlahnya cukup besar."

(Hasil wawancara dengan Yuldi Herman pukul 10.00 Wib hari Kamis tanggal 09 Januari 2020)

“dengan adanya sistem rekruitmen 30\% untuk perempuan dapat berpartisipasi dalam pelaksanaan kegiatan partai politik di Dewan Perwakilan Rakyat Daerah (DPRD) Kabupaten Kerinci , kenyataan tidak dapat mendongkrak jumlah anggota perempuan terpilih untuk dapat berpartisipasi di Dewan Perwakilan Rakyat Daerah (DPRD) Kabupaten Kerinci dikarenakan tidak adanya kualitas yang memadai dari anggota yang direkruitmen oleh partai tersebut."

(Hasil wawancara dengan Edminuddin pukul 14.30 Wib hari Kamis tanggal 09 Januari 2020) 
Berdasarkan dari jawaban informan dapat diinterpretasikan, bahwa partisipasi perempuan di Dewan Perwakilan Rakyat Daerah (DPRD) Kabupaten Kerinci dalam sistem rekruitmen tidak diiringi dengan kualitas kapabilitas dan loyalitas terhadap partai yang dimasukinya, dimana dalam hal ini perempuan direkrut oleh partai tersebut hanya sekedar untuk memenuhi ketercukupan anggota $30 \%$ agar dapat masuk dalam pemilihan.

\section{Persepsi Sosial dan Agama.}

Ketika wawancara dengan informan tentang, bagaimanakah partisipasi perempuan dalam persepsi sosial dan agama di Dewan Perwakilan Rakyat Daerah (DPRD) Kabupaten Kerinci? Jawaban dari informan yaitu:

"secara persepsi sosial dan agama perempuan belum sepenuhnya mendapatkan reaksi yang positif dari masyarakat khususnya dalam masyarakat Kabupaten Kerinci karena secara partisipasi perempuan dalam politik masih dianggap kurang pas hal ini dikarenakan banyak anggota perempuan yang berpartsisipasi di Dewan Perwakilan Rakyat Daerah (DPRD) Kabupaten Kerinci tidak didukung oleh keluarganya khususnya suami karena perempuan idealnya harus menjadi ibu dan istri bagi keluarganya. Partisipasi perempuan di Dewan Perwakilan Rakyat Daerah (DPRD) Kabupaten Kerinci cendrung hanya sebagai untuk pemenuhan kebutuhan kuota anggota perempuan $30 \%$ dalam pemilihan."

(Hasil wawancara dengan Amrizal pukul 10.30 Wib hari Kamis tanggal 09 Januari 2020)

"perempuan belum dapat berpartisipasi sepenuh di Dewan Perwakilan Rakyat Daerah (DPRD) Kabupaten Kerinci dikarena secara persepsi sosial dan agama belum sepenuhnya dapat diterima oleh masyarakat hal dibuktikan karena hanya satu orang yang terpilih di Dewan Perwakilan Rakyat Daerah (DPRD) Kabupaten Kerinci."

(Hasil wawancara dengan Reno Efendi pukul 12.00 Wib hari Kamis tanggal 09 Januari 2020)

"kehadiran perempuan dalam partai politik belum dapat dikatakan maksimal. Hal ini tidak didukung oleh masyarakat secara persepsi sosial dan agama. Karena idealnya perempuan itu tidak memiliki kelebihan-kelebihan anggota laki-laki yang memiliki ketegasan dan kepercayaan diri penuh yang tidak dimiliki oleh perempuan yang secara naluri memiliki sifat keibuan dan lemah lembut yang dapat menghambat langkah perempuan menuju DPRD."

(Hasil wawancara dengan Lisnurbani pukul 11.30 Wib hari Kamis tanggal 09 Januari 2020)

"partisipasi perempuan di Dewan Perwakilan Rakyat Daerah (DPRD) Kabupaten Kerinci berdasarkan persepsi sosial dan agama belum dapat berpartisipasi secara maksimal karena tidak didukung dengan persepsi masyarakat secara sosial dan agama perempuan secara lahiriah lebih idealnya menjadi ibu dan istri bagi keluarganya hanya saja ada beberapa masyarakat menganggap bahwa perempuan juga punya hak untuk menjadi anggoat DPRD."

(Hasil wawancara dengan Yuldi Herman pukul 10.00 Wib hari Kamis tanggal 09 Januari 2020) 
“partisipasi perempuan di Dewan Perwakilan Rakyat Daerah (DPRD) Kabupaten Kerinci belum sepenuhnya dapat mewakili jumlah perempuan karena tidak didukung oleh masyarakat karena secara persepsi sosial dan agama perempuan belum sepenuhnya dapat diterima dengan maksimal hal ini dibuktikan dengan hanya satu orang yang terpilih menjadi anggota Dewan Perwakilan Rakyat Daerah (DPRD) Kabupaten Kerinci."

(Hasil wawancara dengan Edminuddin pukul 14.30 Wib hari Kamis tanggal 09 Januari 2020)

Berdasarkan dari jawaban informan dapat diinterpretasikan, bahwa partisipasi perempuan di Dewan Perwakilan Rakyat Daerah (DPRD) Kabupaten Kerinci secara persepsi sosial dan agama belum dapat diwujudkan secara maksimal karena perempuan idealnya memiliki tugas sebagai ibu dan istri bagi keluarganya sehingga tidak banyak masyarakat yang memilih anggota Dewan Perwakilan Rakyat Daerah (DPRD) Kabupaten Kerinci. partisipasi perempuan dalam hal ini dibuktikan hanya satu orang yang terpilih di Dewan Perwakilan Rakyat Daerah (DPRD) Kabupaten Kerinci. Oleh karena itu secara teori dan aplikasinya memang partisipasi perempuan belum semaksimal sebagaimana peran anggota laki-laki di Dewan Perwakilan Rakyat Daerah (DPRD) Kabupaten Kerinci.

\section{Persepsi Budaya (Kultural)}

Ketika wawancara dengan informan tentang, bagaimanakah partisipasi perempuan dalam persepsi budaya (kultural) di Dewan Perwakilan Rakyat Daerah (DPRD) Kabupaten Kerinci? Jawaban dari informan yaitu:

"secara persepsi budaya (kultural) partisipasi perempuan belum sepenuhnya mendapatkan reaksi yang positif dari masyarakat khususnya dalam masyarakat Kabupaten Kerinci karena secara partisipasi perempuan dalam politik masih dianggap kurang pas hal ini dikarenakan banyak anggota perempuan yang berpartsisipasi di Dewan Perwakilan Rakyat Daerah (DPRD) Kabupaten Kerinci tidak didukung oleh budaya masyarakat yang menganggap perempuan tidak sehebat laki-laki untuk menjadi anggota DPRDyang pada prinsipnya pemimpin lebih pas dimiliki olah laki-laki."

(Hasil wawancara dengan Amrizal pukul 10.30 Wib hari Kamis tanggal 09 Januari 2020)

"perempuan belum dapat berpartisipasi sepenuh di Dewan Perwakilan Rakyat Daerah (DPRD) Kabupaten Kerinci dikarena secara persepsi masyarakat masih menganggap secara budaya perempuan lebih baik dirumah."

(Hasil wawancara dengan Reno Efendi pukul 12.00 Wib hari Kamis tanggal 09 Januari 2020)

"kehadiran perempuan dalam partai politik belum dapat dikatakan maksimal. Hal ini tidak didukung oleh persepsi budaya masyarakat Kabupaten Kerinci. Karena idealnya perempuan itu dipimpin bukan memimpin dan perempuan tidak memiliki kelebihankelebihan seperti anggota laki-laki yang memiliki keterbatasan dalam ruang dan geraknya dimasyarakat."

(Hasil wawancara dengan Lisnurbani pukul 11.30 Wib hari Kamis tanggal 09 Januari 2020) 
"partisipasi perempuan di Dewan Perwakilan Rakyat Daerah (DPRD) Kabupaten Kerinci tidak didukung oleh persepsi budaya (kultural) yang menganggap perempuan tidak memiliki ruang gerak sebagaimana laki-laki untuk menjadi anggoat DPRD.”

(Hasil wawancara dengan Yuldi Herman pukul 10.00 Wib hari Kamis tanggal 09 Januari 2020)

“partisipasi perempuan di Dewan Perwakilan Rakyat Daerah (DPRD) Kabupaten Kerinci belum sepenuhnya dapat mewakili jumlah perempuan karena tidak didukung oleh persepsi budaya masyarakatnya karena partisipasi perempuan belum sepenuhnya dapat diterima dengan maksimal untuk menjadi anggota Dewan Perwakilan Rakyat Daerah (DPRD) Kabupaten Kerinci."

(Hasil wawancara dengan Edminuddin pukul 14.30 Wib hari Kamis tanggal 09 Januari 2020)

Berdasarkan dari jawaban informan dapat diinterpretasikan, bahwa partisipasi perempuan di Dewan Perwakilan Rakyat Daerah (DPRD) Kabupaten Kerinci secara persepsi budaya (kultural) belum dapat diwujudkan secara maksimal karena perempuan tidak memiliki ruang gerak yang sama dengan laki-laki karena perempuan dalam persepsi budaya (kultural) memiliki keterbatasan ruang gerak nya diluar rumah hal ini dibuktikan tidak banyaknya anggota perempuan terpilih di Dewan Perwakilan Rakyat Daerah (DPRD) Kabupaten Kerinci.

\section{Persepsi Masyarakat}

Ketika wawancara dengan informan tentang, bagaimanakah partisipasi perempuan dalam persepsi masyarakat di Dewan Perwakilan Rakyat Daerah (DPRD) Kabupaten Kerinci? Jawaban dari informan yaitu:

"secara persepsi masyarakat perempuan belum sepenuhnya mendapatkan reaksi yang positif dari masyarakat khususnya dalam masyarakat Kabupaten Kerinci karena secara partisipasi perempuan di Perwakilan Rakyat Daerah (DPRD) Kabupaten Kerinci tidak mendapatkan dukungan yang penuh dari masyarakat hal ini dibuktikan hanya satu orang perempuan yang terpilih di Perwakilan Rakyat Daerah (DPRD) Kabupaten Kerinci.”

(Hasil wawancara dengan Amrizal pukul 10.30 Wib hari Kamis tanggal 09 Januari 2020)

"perempuan belum dapat berpartisipasi sepenuh di Dewan Perwakilan Rakyat Daerah (DPRD) Kabupaten Kerinci dikarenakan belum sepenuhnya didukung oleh masyarakat yang menganggap perempuan tidak dapat memimpin sama dengan laki-laki di Dewan Perwakilan Rakyat Daerah (DPRD) Kabupaten Kerinci.”

(Hasil wawancara dengan Reno Efendi pukul 12.00 Wib hari Kamis tanggal 09 Januari 2020)

"kehadiran perempuan dalam partai politik belum dapat dikatakan maksimal. Hal ini tidak didukung oleh persepsi masyarakat idealnya perempuan itu hanya sebagai pendamping bagi laki-laki yang tidak harus menonjol dari laki-laki hal ini lah yang dapat menghambat langkah perempuan menuju DPRD."

(Hasil wawancara dengan Lisnurbani pukul 11.30 Wib hari Kamis tanggal 09 Januari 2020) 
“partisipasi perempuan di Dewan Perwakilan Rakyat Daerah (DPRD) Kabupaten Kerinci berdasarkan persepsi masyarakat belum dapat berpartisipasi secara maksimal karena tidak didukung dengan persepsi masyarakat yang menganggap perempuan secara lahiriah lebih idealnya menjadi ibu dan istri bagi keluarganya."

(Hasil wawancara dengan Yuldi Herman pukul 10.00 Wib hari Kamis tanggal 09 Januari 2020)

"partisipasi perempuan di Dewan Perwakilan Rakyat Daerah (DPRD) Kabupaten Kerinci belum sepenuhnya dapat mewakili jumlah perempuan karena tidak didukung oleh persepsi masyarakat untuk menjadi anggota DPRD."

(Hasil wawancara dengan Edminuddin pukul 14.30 Wib hari Kamis tanggal 09 Januari 2020)

Berdasarkan dari jawaban informan dapat diinterpretasikan, bahwa partisipasi perempuan di Dewan Perwakilan Rakyat Daerah (DPRD) Kabupaten Kerinci secara persepsi masyarakat belum dapat diwujudkan secara maksimal karena masyarakat masih menganggap perempuan idealnya memiliki tugas sebagai ibu dan istri bagi keluarganya sehingga tidak banyak masyarakat yang memilih anggota Dewan Perwakilan Rakyat Daerah (DPRD) Kabupaten Kerinci. Oleh karena itu secara teori dan aplikasinya memang partisipasi perempuan belum semaksimal sebagaimana peran anggota laki-laki di Dewan Perwakilan Rakyat Daerah (DPRD) Kabupaten Kerinci dikarenakan tidak didukung oleh persepsi masyarakat tentang kedudukan perempuan yang belum sepenuhnya sejajar dengan laki-laki.

\section{PENUTUP}

\section{Kesimpulan}

Dari hasil penelitian dan pembahasan dapat disimpulkan bahwa :

1. Partisipasi perempuan secara pendidikan formal di Dewan Perwakilan Rakyat Daerah (DPRD) Kabupaten Kerinci tidak sepenuh dapat dilakukan oleh perempuan karena adanya keterbatasan ruang dan gerak perempuan dalam kancah politik.

2. Partisipasi perempuan di Dewan Perwakilan Rakyat Daerah (DPRD) tidak didukung oleh pengalaman berorganisasi dari anggota perempuan sehingga partisipasi perempuan tidak maksimal karena tidak diiringi dengan pengalaman dalam berorganisasi.

3. Partisipasi perempuan di Dewan Perwakilan Rakyat Daerah (DPRD) Kabupaten Kerinci dalam sistem rekruitmen tidak diiringi dengan kualitas kapabilitas dan loyalitas terhadap partai yang dimasukinya, dimana dalam hal ini perempuan direkrut oleh partai tersebut hanya sekedar untuk memenuhi ketercukupan anggota $30 \%$ agar dapat masuk dalam pemilihan.

4. Partisipasi perempuan di Dewan Perwakilan Rakyat Daerah (DPRD) Kabupaten Kerinci secara persepsi sosial dan agama belum dapat diwujudkan secara maksimal karena perempuan idealnya agama memiliki tugas sebagai ibu dan istri bagi keluarganya sehingga tidak banyak perempuan berpartisipasi di Dewan Perwakilan Rakyat Daerah (DPRD) Kabupaten Kerinci.

5. Partisipasi perempuan di Dewan Perwakilan Rakyat Daerah (DPRD) Kabupaten Kerinci secara persepsi budaya (kultural) belum dapat diwujudkan secara maksimal karena perempuan tidak memiliki ruang gerak yang sama dengan laki-laki karena perempuan dalam persepsi budaya (kultural) memiliki keterbatasan ruang geraknya diluar rumah.

6. Partisipasi perempuan di Dewan Perwakilan Rakyat Daerah (DPRD) Kabupaten Kerinci secara persepsi masyarakat belum dapat diwujudkan secara maksimal karena masyarakat masih 
menganggap perempuan idealnya memiliki tugas sebagai ibu dan istri bagi keluarganya sehingga tidak banyak perempuan yang terpilih di Dewan Perwakilan Rakyat Daerah (DPRD) Kabupaten Kerinci.

\section{Saran} yaitu :

Dari keempat indikator penelitian diatas dan berdasarkan kesimpulan dapat disarankan

1. Partisipasi perempuan dalam pendidikan formal belum dapat mendukung jumlah terpilih di Dewan Perwakilan Rakyat Daerah (DPRD) Kabupaten Kerinci untuk itu diharapkan dapat lebih maksimal pendidikan formal dapat mendukung jumlah keterwakilan perempuan di Dewan Perwakilan Rakyat Daerah (DPRD) Kabupaten Kerinci. Untuk itu perlu ditingkatkan pendidikan formal dari anggota perempuan yang berpastisipasi dalam kancah politik.

2. Partisipasi perempuan dalam pengalaman organisasi dapat ditingkatkan agar keberadaan perempuan dapat lebih diperhitungkan.

3. Partisipasi perempuan dalam sistem rekruitmen diharapkan dapat meningkat agar partisipasi perempuan betul-betul dapat diperhitungkan. Untuk itu perlu adanya perekrutan perempuan yang berkualitas di bidang politik.

4. Partisipasi perempuan dalam persepsi sosial dan agama diharapkan dapat sepenuhnya diterima oleh masyarakat, untuk itu perlu ditingkatkan sosialisasi kepada masyarakat akan pentingnya partisipasi perempuan di DPRD Kabupaten Kerinci untuk mewakili suara dari masyarakat perempuan.

5. Partisipasi perempuan di Dewan Perwakilan Rakyat Daerah (DPRD) Kabupaten Kerinci secara persepsi budaya (kultural) hendak dapat menerima kebaradaan perempuan dikancah politik untuk itu perlu adanya sosialisasi terhadap pola pikir masyarakat bahwa perempuan juga dapat berpartisipasi sejajar dengan laki-laki.

6. Partisipasi perempuan di Dewan Perwakilan Rakyat Daerah (DPRD) Kabupaten Kerinci dapat ditingkatkan. Untuk itu perlu adanya dukungan dari masyarakat dengan merobah persepsi masyarakat melalui sosialisasi oleh partai agar partisipasi perempuan dapat ditingkatkan secara kuantitas. 


\section{DAFTAR PUSTAKA}

Abdullah, Iwan, 2006, Sangkan Paran Gender, PustakaPelajar,Yogyakarta.

Affifah, Neng Dara, 2005, Gender \& Islam, Kapal Perempuan, Jakarta.

Anugrah, A. (2009). Keterwakilan Perempuan Dalam olitik. Jakarta: Pancuran Alam.

Badjuri, Abdul Kahar \& Yuwono, Teguh, 2002, Kebijakan Publik Konsep dan Strategi, Universitas Diponegoro, Semarang.

Budiardjo, P. M. (2008). Dasar-Dasar Ilmu Politik (Revisi ed.). Jakarta: Gramedia Pustaka Utama.

Darwin, Muhadjir, 2005, Negara dan Perempuan (Reorientasi Kebijakan Publik), Adipura, Yogyakarta.

Dwijowiyoto, Nugroho, Riant, 2003, Kebijakan Publik, Formulasi, Implementasi dan Evaluasi, Gramedia , Jakarta.

Dwiyanto, Agus, dkk, 2002, Reformasi Birokrasi Publik di Indonesia, Gadjah Mada, University Press, Yogyakarta.

Hafiz Liza, 2004, $\quad$ Perempuan Dalam Wacana Politik Orde Baru, Pustaka LP3ES, Jakarta.

Hefner, RobertW 2007, Politik Multikulturalisme, Menggugat Realitas Kebangsaan, Kanisius, Yogyakarta.

Islamy, Irfan, 1999, Kebijakan Publik, Modul UT, Universitas Terbuka, Jakarta.

Isbodroini Suyanto. "Peranan Sosialisasi Politik terhadap Partisipasi Politik Perempuan", dalam Kajian Pembangunan Wanita. Jakarta: Yayasan Obor Indonesia, hlm. 489.

Jurnal Perempuan 35, 2000 ,Politik dan Keterwakilan Perempuan, Yayasan Jurnal Perempuan Jakarta,

Luky Sandra Amalia, "Marjinalisasi Perempuan Dalam Politik Pada Pemilu 2009", Jurnal Masyarakat Indonesia Edisi Khusus, LIPI Press: 2009.

Mansour Fakih, 2001, Sesat Pikir Teori Pembangunan dan Globalisasi, Pustaka Pelajar, Yogyakarta.

Mas'oed Mohtar, 2000, Perbandingan Ilmu Politik, Gadjah Mada University Press, Yogyakarta.

Mulyana W. Kusuma. 2000. Menata Politik Pasca Reformasi, hal 28 KIPP, Jakarta.

Napsiah. (2009). Gender and Politics. Nilai-Nilai Profetik dan Affirmative Action di Partai Politik, 171.

Nataresmi. (2014). Philips J. Vermonte: Problem Representasi Perempuandalam Politik. Jakarta: Yayasan Jurnal Perempuan.

The Macmillan Company. Huntington, Samuel P., \& Nelson, Joan. (1994). Partisipasi Politik di Negara Berkembang. Jakarta: Rineka Cipta

\section{Peraturan Perundang-Undangan}

Undang-Undang Republik Indonesia Nomor 31 Tahun 2002 tentang Partai Politik

Undang-Undang Republik Indonesia Nomor 12 Tahun 2003 tentang Pemilihan Umum

Undang-Undang Republik Indonesia Nomor 2 Tahun 2008 tentang Partai Politik

Undang-Undang Republik Indonesia Nomor 10 Tahun 2008 tentang Pemilihan Umum 